\title{
COMPARISON OF THE PERFORMANCE OF SOES BANKS AND PRIVATE BANKS AND ITS INFLUECE TO THE STOCK PRICES
}

\author{
Husnul Insan*1, Yusman Syaukat" ${ }^{* *}$, and Imam Teguh Saptono*) \\ *) School of Business, Bogor Agricultural University \\ Pajajaran Road, Bogor 16151 \\ **) Department of Resource and Environmental Economics, Faculty of Economics and Management, \\ Bogor Agricultural University \\ Jl. Agatis, IPB Darmaga Campus, Gd. Faculty of Economics and Management W3 L2 Bogor, 16680
}

\begin{abstract}
Banking industry is one of the industries which show the presence of tight competition. The competition itself can be seen from the number of banks which operates in Indonesia in 2014, that is 119 banks. The aim of doing this research is to analyze the different financial performances between Significant effect on the level of 5\% and Private banks, and also to analyze the variable influence of bank finance performances to the stock price. The analyzing method which will be used on this research is radar and regression analyzing graphic illustration techniques. The result of this research shows that financial performances of SEOs Banks is better than Private Banks according to the profitability, productivity, and growth potential aspect, while on the aspect of liquidity, private banks has a better performance than SOEs banks. In terms of solvability, both banks have the same financial performances. According to the regression analysis, it is known that the bank financial performance on CAS and NIM variable has a positive and significant influence to the stock prices, while on LDR, CRR, CAR, DRR, and ROA variables they have a negative and significant influence to the stock prices. This shows that the investors have made those variables as a benchmark in their investing policies and they tend to pursue the stocks from SOEs banks rather than private banks, because generally SOEs banks have a better financial performance than private banks.
\end{abstract}

Keywords: regression analysis, bank, stock prices, financial performances, radar method

Abstrak: Industri perbankan merupakan salah satu industri yang menunjukan adanya persaingan yang begitu ketat. Persaingan tersebut dapat dilihat dari banyaknya jumlah bank yang beroperasi di Indonesia pada tahun 2014, yaitu sebanyak 119 bank. Adapun tujuan dari penelitian ini adalah menganalisis perbandingan kinerja keuangan antara kelompok bank BUMN dan bank swasta, dan menganalisis pengaruh variabel kinerja keuangan bank terhadap harga saham. Metode analisis yang digunakan pada penelitian ini adalah teknik ilustrasi grafis radar dan analisis regresi. Hasil dari penelitian ini menunjukkan bahwa kinerja keuangan bank BUMN lebih baik daripada bank swasta berdasarkan pada aspek profitabilitas, produktivitas dan potensi pertumbuhan, sedangkan pada aspek likuiditas, bank swasta memiliki kinerja yang lebih baik daripada bank BUMN. Dan dari segi solvabilitasnya, kedua kelompok bank memiliki kinerja keuangan yang sama. Berdasarkan hasil analisis regresi, diketahui bahwa kinerja keuangan bank pada variabel CAS dan NIM memiliki pengaruh yang positif dan signifikan terhadap harga saham, sedangkan pada variabel LDR, CRR, CAR, DRR, CIR dan ROA memiliki pengaruh yang negatif dan signifikan terhadap harga saham. Hal ini menunjukkan bahwa para investor menjadikan variabel-variabel tersebut sebagai tolak ukur dalam kebijakan investasinya dan invetor cenderung akan memburu saham dari bank BUMN dibandingkan dengan bank swasta, karena secara umum bank BUMN memiliki kinerja keuangan yang lebih baik daripada bank swasta.

Kata kunci: analisis regresi, bank, harga saham, kinerja keuangan, metode radar

\footnotetext{
${ }^{1}$ Corresponding author:

Email: husnul.insan@yahoo.com
} 


\section{INTRODUCTION}

Nowadays banking industry is one of the industries which show a tight competition. A tight competition can be seen from the number of banks which operates in Indonesia. From Indonesian Banks' statistical data per end of the year in December 2014, the number of commercial banks which operates is about 119 banks which consist of 4 State-Owned (SOEs) Banks, 38 private national bank (BUSN) foreign exchanges, 29 BUSN non-foreign exchanges, 26 BPD, 12 mixed banks and 10 foreign banks. Competition among groups of banks in Indonesia is clearly seen in SOEs banks and commercial banks (foreign exchange) if it is seen from its total market share, where SOEs banks and commercial banks are able to dominate the industrial market shares in national banks by $76 \%$.

According to Indonesian Banks's statistical data per end of the year in December 2014, it is said that SOEs banks group is noted to experience a considerable increase in office number which is 783 offices (branch office, branch office aide, and cash office), while in national commercial banks group (foreign exchange) the increase is only 261 offices. Therefore, it can be concluded that SOEs bank is a quite aggressive bank in executing their business network development, considering that there are only four banks. According to the number of assets in 2010-2014, the compound growth rate of SOEs bank group is higher than that of commercial banks, which is $17.19 \%$ compared to $15.08 \%$. According to Tanggulungan (2012), government banks have the advantage of a strong capital because the major ownership is the government, so it is perceived as a bank that in terms of capital and performances will always be supported by the government.

On deciding the performance of a bank that is better than another bank, a ratio analysis of the bank financial statement is truly needed. The analyzing tool which is used is a ratio analysis with radar method. According to Hermanto (1993), radar method is a visual description of the company's performance ratio calculation overview which is the improvement of financial ratio analysis. The benefit of it is to give a full description of the company position and the possible developments. Radar analysis is capable to give a medium and long term insight if compared to traditional ratio analysis (dupont) which is short term (Hermanto, 1993). Radar method is a perfect conventional financial ratio because of another additional indicator, which is company's growth potential analysis, which can be used as a benchmark for observing the company's progress. Another advantage which can be identified is having the same weight or interest to its every financial aspect, so if a bank couldn't afford to maintain its financial performance of every aspect, the bank could have problems with its business, whether it is short term or even long term.

Financial performance can also be a base for the investors to choose their investment, because it relates to the prediction or the increasing or decreasing stock prices of a company. Devitra (2013) expresses that the better the performance of a company the higher the profit of their business and the more benefit that could be enjoyed by the shareholders, also the bigger the chances of ascending stock prices. When choosing the required stock, there is an analysis tool or an approach which will be used as an assessment of a stock. One of the approaches which will be used by the investors to assess the fairness of a stock price in a stock exchange is price earning ratio (Guler dan Yimaz, 2008). Hayati (2010) explains that the main reason why price earning ratio (PER) is used in a stock price analysis is because PER will simplify and assist analysts and investors in assessing stocks, other than that PER can also assist analysts in correcting judgement because the present stock price is the reflection of the company's prospect in the future. Stocks with high PER assessment give an indication that the future prospect of those stocks will be great and will reflect the high company stock prices (Purwaningrum, 2011).

According to the background description, it is shown that there is a competition between SOEs banks group and private banks when it is seen from the asset growth of both parties, where private banks are able to be near the gain of SOEs banks, even though private banks have lower business network development than SOEs banks. Nevertheless, the previous research result shows that financial performance of SOEs banks is not always better than private banks. In fact, the financial performance of both parties can be said as equal. This is disclosed by Ahmad et al. (2014), who says that the average liquidity performance rate of private banks are slightly better than that of SOEs banks; however, for the profitability performance, SOEs banks are better than private banks, while the modal sufficiency of both bank groups are not significantly different or the same. According to Nasta (2004), it is concluded that the financial performance of national commercial 
foreign exchange banks with radar method according to aspect of liquidity, capital, productivity, profitability, and growth possibility shows that the condition is not well, but capital to total asset ratio and loan to deposit ratio variable shows that it is fine.

In this research there is also stock prices analysis. It is intended to see the variables of bank's financial performances which are most appreciated by the investors or the capital market as an investment decision makers. Haryetti (2012) explains that company's financial performances will affect the stock prices, because information from the financial report or financial ratio will give an impact to the investors' decision on investing their asset. In Wijayanti's (2010) research, it is said that Net Interest Margin (NIM) and Return on Asset (ROA) variables have a negative and significant impact on the bank's stock prices in Indonesia Stock Exchange (IDX). According to those descriptions, the problem formulation which is discussed in this research is how the financial performance of SOEs bank groups and private banks are different, and how bank financial performances variable affects the stock prices.

The aim of this research is to analyze the comparison of financial performance of SOEs bank groups and private banks with radar method, and also to analyze the effects of bank financial performances variable to the stock prices.

\section{METHODS}

The type of data used is a secondary data from a yearly financial report (annual report) that were published in 2010-2014. This data source is obtained from each bank's website and Indonesia Stock Exchange. The sample population which is used in this research is SOEs bank groups and private banks. Sampling is done by purposive sampling technique. Purposive sampling is a sample choosing technique based on certain criteria or purpose. The criteria are as follows:

1. Banks which are listed in Indonesia Stock Exchange and have published yearly financial report (annual report) in year 2010-2014.

2. Commercial banks form SOEs and national private banks.

3. Banks which have been listed in top 12 biggest banks in Indonesia according to the 2014 assets.
According to the technique and criteria of sampling, there are four SOEs banks and eight national private banks. SOEs bank groups are Bank Mandiri, Bank Rakyat Indonesia, Bank Negara Indonesia, and Bank Tabungan Negara, while national private bank groups are Bank Central Asia, Bank CIMB Niaga, Bank Danamon, Bank Permata, Bank Panin, Bank Internasional Indonesia, Bank OCBC NISP and Bank Bukopin.

\section{Radar Analysis}

This analysis is used as a decision making in comparing the financial performance of both parties according to radar ratio analysis. This financial performance comparison is based on graphic illustration which is built based on the created scale system. This scale is created with minimalizing the ratio value with the range 1-10. The definition and calculation of each ratio variable which is used in this research can be seen in Table 1.

\section{Stock Price Determinant Analysis}

This analysis is done to discover the effect of bank's financial performance on price earning ratio or to discover the bank's financial performance variables which are most appreciated by the investors or the stock market as a decision maker of their investment, during the 2010-2014 period. The analysis tools which are used to discover it is a multiple linear regression analysis. Dependent variable which is used is PER, as an indicator of stock prices. PER can be formulated as follows (Pasaribu, 2008):

PER $=$ Market Price per Share/ Earning per Share

The regression model from this research can be formulated as follows:

$$
Y=\alpha+\beta 1 X 1+\beta 2 X 2+\beta 3 X 3+. .+\beta 16 X 16+e
$$

Explanation: Y(Price earning ratio); $\alpha$ (Constants); $\beta 1$ $\beta 16$ (Regression coefficient); X1-X15 (Financial ratio variable); e (Residual); X16 (Dummy value (1= SOEs and $0=$ private)).

Control variables (dummy) are put in this regression model in a form of banks to control the possibilities of a different effect on PER between SOEs banks and private banks. 
Table 1. Definition and calculation of bank's financial performance ratio

\begin{tabular}{|c|c|c|c|}
\hline Indicator & Variable & Variable Definition & How to Calculate \\
\hline \multirow[t]{3}{*}{ Liquidity } & CRR & $\begin{array}{l}\text { The ratio which is used to measure the bank risks on credits that } \\
\text { cannot be paid back by its debtors, both the debt and its interest } \\
\text { (Pratiwi, 2001) }\end{array}$ & Bad debts / Total loan \\
\hline & LDR & $\begin{array}{l}\text { The ratio to measure how big the fund used to finance the credits } \\
\text { (Nasta, 2004) }\end{array}$ & Total loan / Total deposit \\
\hline & LRR & $\begin{array}{l}\text { The ratio which describes bank risks related to whether the banks } \\
\text { are capable or not to return the deposit of their depositors with } \\
\text { liquid asset which they own, right after the bank fulfilled their } \\
\text { short term responsibilities (Pratiwi, 2001) }\end{array}$ & $\begin{array}{l}\text { (Liquid asset }- \text { Short } \\
\text { term borrowing ) / Total } \\
\text { deposit }\end{array}$ \\
\hline \multirow[t]{3}{*}{ Solvability } & CAS & $\begin{array}{l}\text { The ratio which describes how big the capital ability which is } \\
\text { available to cover the loss if there is total asset loss (Nasta, 2004) }\end{array}$ & $\begin{array}{l}\text { Equity capital / Total } \\
\text { asset }\end{array}$ \\
\hline & CAR & $\begin{array}{l}\text { The capital ratio which shows the bank performance in } \\
\text { supporting assets that contains or produces risks (Dendawijaya, } \\
\text { 2003) }\end{array}$ & $\begin{array}{l}\text { (Tier1+Tier2) / Risky } \\
\text { asset }\end{array}$ \\
\hline & DRR & $\begin{array}{l}\text { Variables which are used to measure banks capability on } \\
\text { paying back the fund which is stored by their depositors, whose } \\
\text { payment is guaranteed by its own capital bank (Nasta, 2004) }\end{array}$ & $\begin{array}{l}\text { Equity capital / Total } \\
\text { deposit }\end{array}$ \\
\hline \multirow[t]{3}{*}{ Productivity } & BOPO & $\begin{array}{l}\text { The ratio which is used to measure the bank's level of capability } \\
\text { of operating their activities (Dendawijaya, 2003) }\end{array}$ & $\begin{array}{l}\text { Operating expense / } \\
\text { Operating income }\end{array}$ \\
\hline & CIR & $\begin{array}{l}\text { The efficiency ratio or cost income ratio, to measure the cost } \\
\text { efficiency level which is issued by the bank to run the business } \\
\text { (Kurt and Graham, 2004) }\end{array}$ & $\begin{array}{l}\text { Non interest expense / } \\
\text { (Net interest income }+ \\
\text { Non interest income) }\end{array}$ \\
\hline & EPE & $\begin{array}{l}\text { EPE is used to measure the capability of a bank to control the } \\
\text { burden of each worker (Pratiwi, 2001) }\end{array}$ & $\begin{array}{l}\text { Employee expense / } \\
\text { Total employee }\end{array}$ \\
\hline \multirow[t]{3}{*}{ Profitability } & ROA & $\begin{array}{l}\text { ROA is used to measure the bank management capability to } \\
\text { obtain the overall profit. The bigger the ROA value, the bigger } \\
\text { the profit is obtained and also the better the bank position in } \\
\text { terms of using assets (Nasta, 2004) }\end{array}$ & $\begin{array}{l}\text { Net income before tax / } \\
\text { Total asset }\end{array}$ \\
\hline & $\mathrm{ROE}$ & $\begin{array}{l}\text { ROE is used to measure the capability of bank management to } \\
\text { obtain the net profit. The bigger the ROE value, the bigger also } \\
\text { the income level of the stockholder (Pratiwi, 2001) }\end{array}$ & $\begin{array}{l}\text { Net income / Equity } \\
\text { capital }\end{array}$ \\
\hline & NIM & $\begin{array}{l}\text { NIM is used to measure the management capability to deal with } \\
\text { the large interest expenses from every asset that produces results/ } \\
\text { earning assets (Nasta, 2004) }\end{array}$ & $\begin{array}{l}\text { (Interest income - } \\
\text { interest expense) / } \\
\text { Earning asset }\end{array}$ \\
\hline \multirow[t]{3}{*}{$\begin{array}{l}\text { Growth } \\
\text { possibility }\end{array}$} & EB & $\begin{array}{l}\text { The ratio which is used to discover the ability of each branch to } \\
\text { expand its business connection with human resource capacity } \\
\text { which they own (Pratiwi, 2001) }\end{array}$ & Total employee / Branch \\
\hline & OIB & $\begin{array}{l}\text { This ratio is connected to the ability of each branch to produce } \\
\text { bank's income (Nasta, 2004) }\end{array}$ & $\begin{array}{l}\text { Operating income / } \\
\text { Branch }\end{array}$ \\
\hline & $\mathrm{V} 2$ & $\begin{array}{l}\text { This ratio is connected to the ability of each workers to produce } \\
\text { bank's income (Nasta, 2004) }\end{array}$ & $\begin{array}{l}\text { Operating income / Total } \\
\text { employee }\end{array}$ \\
\hline
\end{tabular}

Partial individual test

Partial test is used to discover the real effect from each independent variable individually to its dependent variables. This testing can be done by comparing the probability values with $\alpha(\alpha=5 \%)$.

There are five radar method aspects which are used to assess bank's financial performances, which are liquidity, solvability, productivity, profitability, and bank growth potential ratio (Nasta, 2004). These ratio groups are then compared with the financial performance of SOEs banks and private banks according to the graphic radar. This research also analyzes the stock prices; the goal is to know the effect of bank's financial performance variable to PER using regression analysis. The outline of the framework of this research can be seen in Figure 1 . 


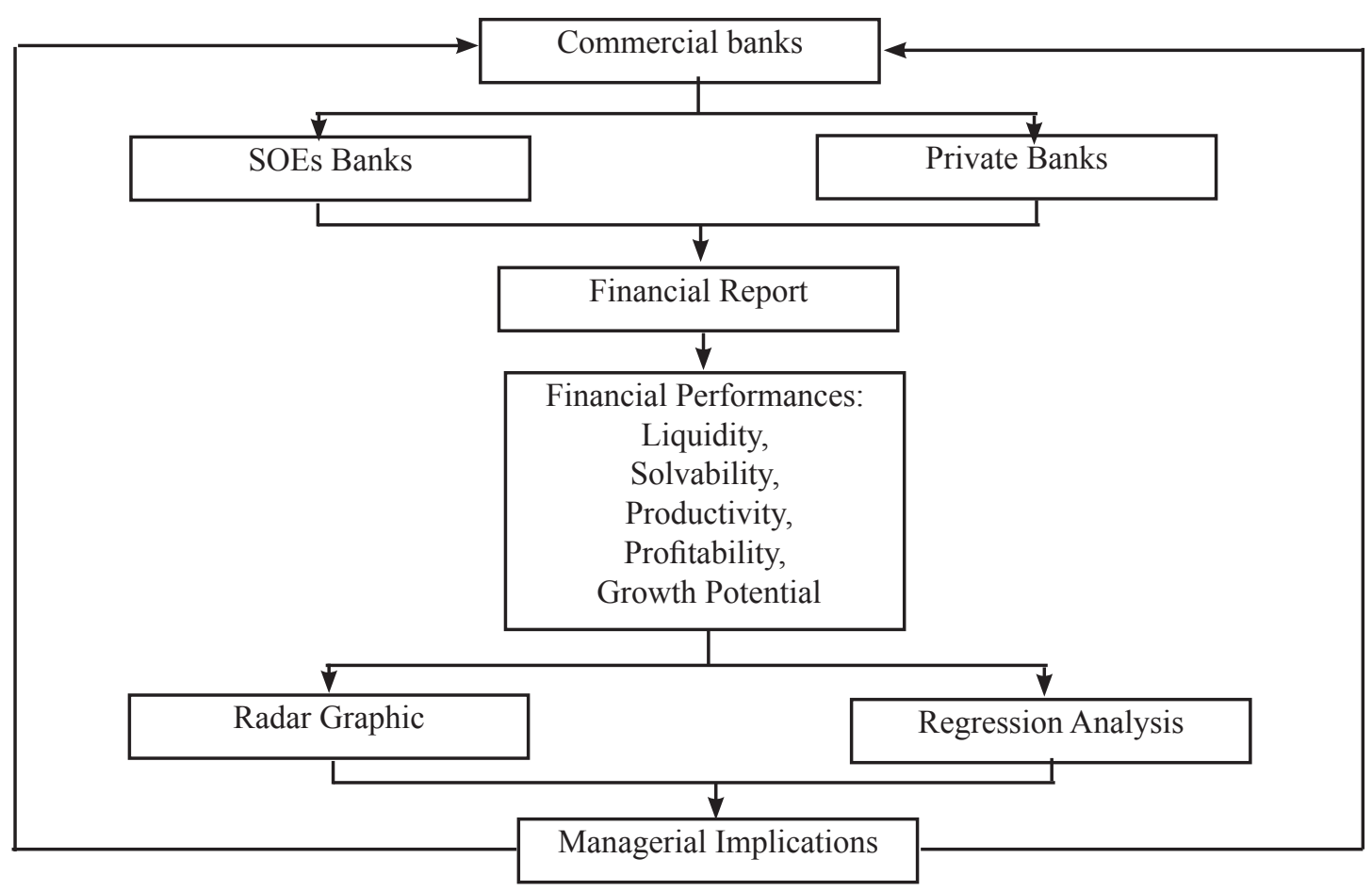

Figure 1. Research framework

\section{RESULTS}

\section{Bank's Financial Performance Radar Analysis}

The financial performance for liquidity aspect is quite the same, except the credit risk ratio variable which shows private banks' financial performance is better than SOEs banks' (Figure 2). This shows that private banks has fewer problems in the number of credits or has a better debtor quality than SOEs banks. This discovery result is in line with the research from Kapur and Gualu (2012), which sums up that private banks have a better credit quality than government banks in Ethiopia in 2001-2008 period. The same goes for the discovery from Mewengkang (2013) and Jamaluddin (2012) research, which sums up that there are no real differences on LDR performances between government banks and national private banks.

In Figure 3, it is shown that the financial performances on solvability aspect of SOEs banks and private banks are quite the same, either on CAS, CAR, or even DRR variables. It means that both bank groups have the same capital ability on anticipating every risk which appears from its operational activities. This is because Bank of Indonesia is very strict on deciding the minimum capital than the other provision, so every banking business strengthens their capital position. This research is in the same line as the research from Marsuki et al. (2012), which sums up that there are no real differences between government and national private bank's CAR performances in the 2006-2011 periods. The same goes for Kapur and Gualu (2012) research, which mentions that there are no real differences on bank's capital management on capital to assets and capital to deposits between government and private banks in Ethiopia in the 2001-2008 periods.

It can be seen in Figure 4 labor costs ratio performance (EPE) between SOEs banks and private banks are quite the same, while in BOPO and CIR variables, SOEs banks have a better performance than private banks. The factor that costs an operational burden on private banks is the bank's huge funding sources which are obtained from debt, and the deposit interest rate which is applied by private banks is quite higher than SOEs banks, so that the interest expenses that must be borne by private banks is bigger, while the high overhead costs on private banks is caused by large amount of general and administration costs and other expenses outside the labor costs. This statement is also stated by Farazi et al. (2011), which mentions that government banks is more efficient in expenses management than private banks, especially overhead cost which is issued by banks. The result of Tanggulungan's (2012) research, which mentions that there was no real difference between government and private bank's BOPO financial performances in the 2002-2010 period, so are the research done by Kapur and Gualu (2012), which sums up that there was no real difference which was 
measured by cost to income ratio between government and private bank's efficiency performance in Ethiopia in the 2001-2008 period.

Financial performance on the profitability aspect of SOEs bank groups is better than that of private banks from its three ratio variables (Figure 5). This shows that SOEs banks have the ability to manage assets and capital much more effectively and optimally in producing higher interest or profit income for the company rather than private banks. It means that every additional asset and capital which is done by SOEs banks is able to produce higher interests or profit interest than private banks. This result is different from the research done by Purwoko and Sussanto (2008), which stated that ratio performance of net interest margin (NIM), return of equity (ROE) and return of asset (ROA) which will be achieved by government banks are not significantly different from private banks' achievement in the 20012006 periods.

In Figure 6, it is shown that operating income per employee's performance from both groups of bank is quite the same, while for the employee per branch and operating income per branch performances of SOEs bank's group has a better performance than private banks. This shows that SOEs banks has better business growth potential than private banks, according to bank's ability to expand their business network and to produce operational income from all of its branch. It means that employees' addition which is done by SOEs bank on its every branch are able to expand their bank's business network or their work unit compared to private banks, and this, of course, influences the bank's operational higher income which is produced from all of its branch.

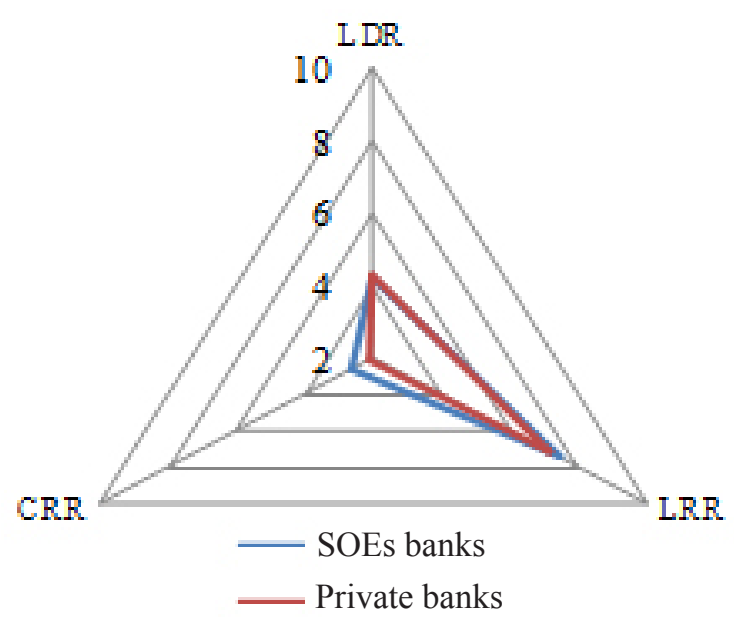

Figure 2. Financial performances of liquidity aspect

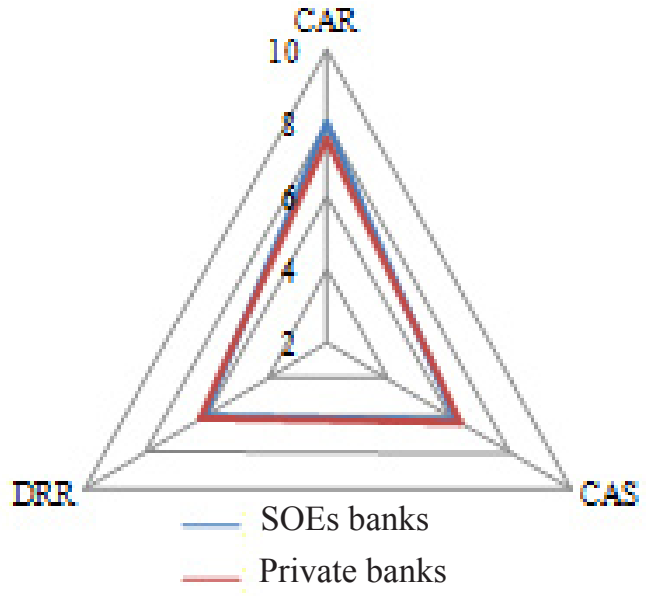

Figure 3. Financial performances of solvability aspect

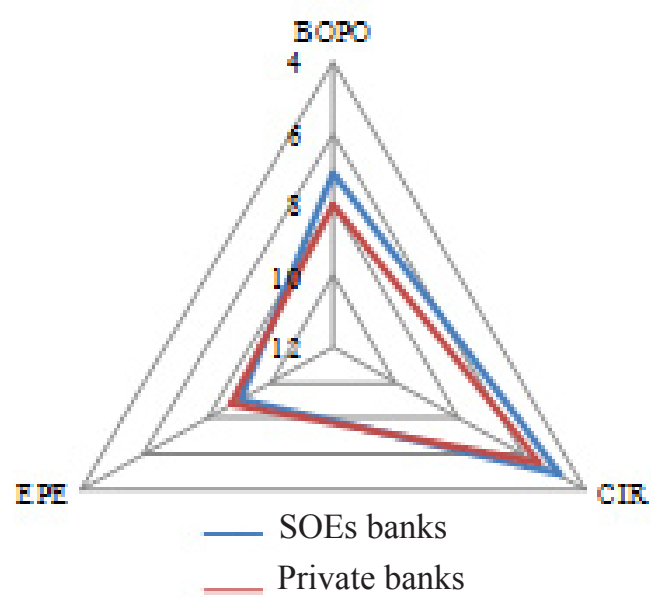

Figure 4. Financial performance of productivity aspect

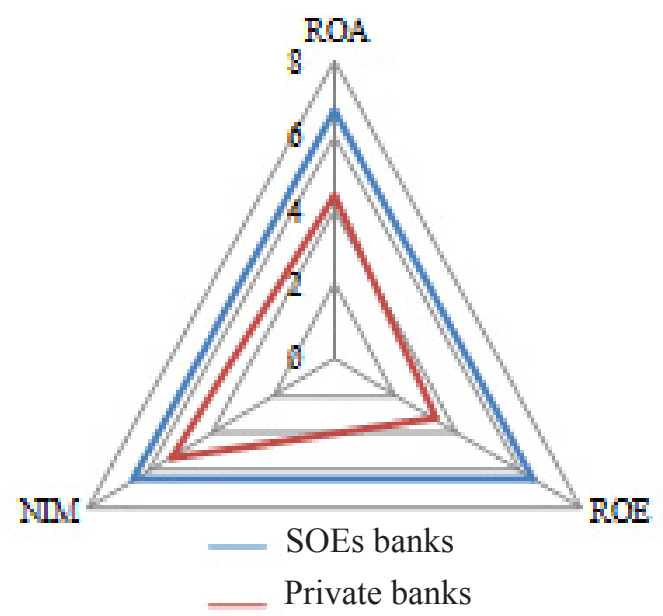

Figure 5. Financial performance of profitability aspect 


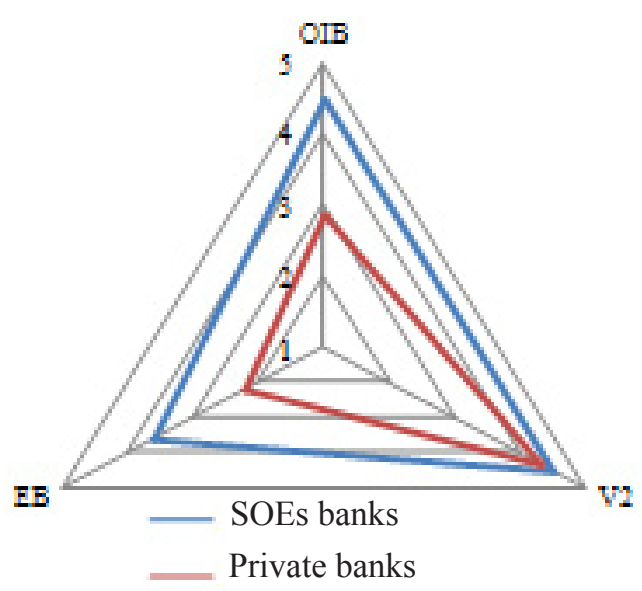

Figure 6. Financial performances of growth potential aspect

\section{Determinant Analysis of Stock Prices}

From the result of multiple linear regression analysis in Table 2 , the probability value of test-F is smaller than the significant value by $5 \%(\alpha<0.05)$, so the regression capital could be said fine and independent variable can be used at the same time to explain the dependent variables. The regression analysis estimated value shows that financial performances on CRR, LDR, CAR, DRR, CIR, and ROA value affect PER significantly and the effect's direction is negative or contradicts to PER. It means that every time there is an increase in each ratio value, there will also be a decrease in PER value, with the assumption that the other variables are stable (ceteris paribus). The results from CRR, LDR and CIR performances are in the same line with the existing theory. Just like what has been explained before that CRR and LDR variable is an indicator from the bank liquidity, while CIR is one of the bank's productivity indicators. So if there is a decrease in each ratio value, then those banks have a good liquidity and productivity level and this will affect the height of banks' PER value.

Unlike the results obtained from CAR, DRR and ROA variables are unique findings because they are not in the same line with the existing theory. The higher the value of the three ratio, the higher their PER value, because CAR and DRR variables are indicators of solvability or the capital ability of a bank, while ROA is one of the indicators of bank's solvability. This phenomenon can happen because of the bank's short term big capital growth or because of the increasing active value which contains risks (ATMR) and the bank third party's fund which is bigger than the capital increase.

This is responded negatively by the investors, because if a bank has an increasing ATMR and DPK value, then the possibilities of risks and obligations which will be borne by the bank in the later days will also get bigger, so the investors consider that the bank's stock doesn't have a good prospect in the future. Therefore, it can be assumed that banks with higher CAR and DRR values but don't follow the right risks management, so those banks will have a problem in the future and will make an adverse impact to the company's image through their PER values. This condition can be a concern to the second bank groups, because either SOEs bank or private banks have the same CAR and DRR performance, so the impact which will occur to the movement of the PER value will be felt by both groups. This also happens in the research of Devitra (2013) which sums up that CAR variable has a negative and significant effect on the bank's return stock in BEI.

The same goes to ROA gaining values which have a negative response from the investors. These conditions happen because of gaining ROA or big profit but not sustainable or there is a bigger bank's asset growth than the profit. This shows that banking ROA values experience fluctuation and the banks are less optimal in making profits with the number of assets they have. This of course becomes a concern for each bank, because with the fluctuation of the bank ROA values, it will make the dividend the investors will receive uncertain, because ROA reflects the profit level which is produced by a bank. According to Sutriani (2014), the higher the ROA, then the dividend which will be received by the shareholders will increase. Therefore, for every bank, maintaining their ROA performances high and consistent is a must, because investors will believe in the banks with stable profit for investment.

This condition of course becomes an exclusive concern for SOEs banks because they have higher ROA than private banks, so if SOEs banks are able to maintain their ROA performance, then their PER values will be higher than private banks and vice versa. These results also happen in the research of Wijayanti (2010), which mentions that ROA variables have a negative and significant effect on stock prices in BEI. 
Table 2. Multiple linear regression analysis result

\begin{tabular}{lccc}
\hline $\begin{array}{l}\text { Independent } \\
\text { variable }\end{array}$ & $\begin{array}{c}\text { Regression } \\
\text { coefficient }\end{array}$ & t-count & Sig. \\
\hline Constants & 139.11 & 1.81 & 0.077 \\
CRR & -7.81 & -2.69 & $0.010^{*}$ \\
LDR & -0.49 & -2.03 & $0.048^{*}$ \\
LRR & -2.87 & -1.96 & 0.056 \\
CAS & 18.13 & 3.02 & $0.004^{*}$ \\
CAR & -4.07 & -2.62 & $0.012^{*}$ \\
DRR & -9.12 & -2.15 & $0.037^{*}$ \\
BOPO & 0.40 & 0.54 & 0.593 \\
CIR & -1.38 & -3.13 & $0.003^{*}$ \\
EPE & -0.11 & -1.40 & 0.169 \\
ROA & -28.98 & -4.05 & $0.000^{*}$ \\
ROE & 0.08 & 0.18 & 0.859 \\
NIM & 11.21 & 3.64 & $0.001^{*}$ \\
EB & 0.59 & 1.08 & 0.284 \\
OIB & 0.00 & -0.67 & 0.508 \\
V2 & 0.02 & 1.80 & 0.079 \\
Dummy & 15.19 & 2.60 & $0.013^{*}$ \\
\hline
\end{tabular}

F-count $=5.809$

Probability (Sig. F) $=0.000^{*}$

*) Significant effect on the level of 5\%

For capital of asset ratio and net interest margin variables, the direction of the influence is positive or in the same line as PER. It means that each ratio value that increases will also increase the PER values, with the assumption that other variables stay the same (ceteris paribus). Both results are in the same line with the theory, remembering that CAS variable is one of the solvability indicators, while NIM is an indicator from bank's profitability. The findings of NIM performances are different from those in Wijayanti's research (2010), which stated that NIM variables have a negative and significant effect on the bank's stock prices in BEI in the 2005-2009 periods.

Bank's control variable has positive and significant influence on PER. It means that SOEs banks give possible bigger influence on the PER's value movement than private banks. Overall, it can be said that the influence on PER can be felt bigger by SOEs banks, because generally speaking SOEs banks have better financial performance than private banks. It means that if SOEs banks have better and more consistent financial performance, then the PER value of SOEs banks is possible to be higher than private banks, and investors tend to go for the stocks from SOEs banks, and vice versa.

\section{Managerial Implication}

For SOEs banks, banking must be implemented with care in giving credits or must be more selective in finding the right debtor to press the collectability numbers especially for BTN bank which has the highest collectability ratio value. For private banks, banking must decrease their dependency on debt as their funding source and focus more on their operational expenses, especially their overhead costs. They also should optimize their workers and branch's development, because by optimizing their branches and workers, those banks will get a bigger profit and they could get a better growth potential. This thing can also influence the trust of bank stakeholders or even investors to stay and use those bank's services. For the investors, they should overlook each variable which will influence PER. According to standardized coefficients value, the investors could pay attention to capital of asset ratio variable, because those variables are the most dominant variables in influencing the price earning ratio.

\section{CONCLUSIONS AND RECOMMENDATIONS}

\section{Conclusions}

SOEs banks' financial performance is better than private banks', according to its profitability, productivity and growth potential aspects, while on its liquidity aspect, private bank's financial performances are better than SOEs bank's. According to the regression analysis results, it is known that bank's financial performances on CAS and NIM variables have a positive and significant influences on the stock prices, while LDR, CRR, CAR, DRR, CIR, and ROA variables have negative and significant influence on the stock prices, and also SOEs bank's stock tend to be more appreciated by investors than private banks.

\section{Recommendations}

This research only consists of 12 bank samples and two groups of banks; therefore, the upcoming researcher should increase the number of samples and groups of banks, so the results will be more generalized. With the rareness of using radar method, further research needs to combine it with other methods, such as CAMEL, EVA (economic value added) or balanced scorecard method, so that the results will be more comprehensive. 


\section{REFERENCES}

Ahmad GN, Renofa N, Mardiyati U. 2014. Analisis kinerja perbandingan bank devisa BUMN dan bank devisa swasta pada tahun 2006-2011. Jurnal Riset Manajemen Sains Indonesia 5(1): 100-122.

Bank Indonesia. 2014. Statistik Perbankan Indonesia Bulan Desember 2014. Jakarta: Bank Indonesia.

Dendawijaya. 2003. Manajemen Perbankan. Cetakan ke-3. Jakarta: Ghalia Indonesia.

Devitra J. 2013. Kinerja keuangan dan efisiensi terhadap return saham perbankan di Bursa Efek Indonesia periode 2007 - 2011. Jurnal Keuangan dan Perbankan 15(1): 38-53.

Guler A, Yimaz MK. 2008. Price earnings ratio, dividend yield and market to book ratio to predict return on stock market: evidence from the emerging markets. Journal of Global Bussines an Technology 4(1): 18-30.

Haryetti. 2012. Analisis pengaruh kinerja keuangan terhadap harga saham pada perusahaan perbankan yang go publik di Bursa Efek Indonesia. Jurnal Sosial Ekonomi Pembangunan 3(7): 88-102.

Hayati N. 2010. Faktor-faktor yang mempengaruhi Price Earning Ratio (PER) sebagai salah satu kriteria keputusan investasi saham perusahaan real estate dan property di bursa efek Indonesia. Jurnal Manajemen dan Akuntansi 11(1): 53-62.

Hermanto B. 1993. Memperkenalkan analisa rasio dengan metoda radar. Majalah Usahawan $5 \mathrm{TH}$ XXII Mei.

Jamaluddin. 2012. Perbedaan kinerja keuangan bank pemerintah dengan bank swasta nasional yang terdaftar di Bursa Efek Indonesia. Jurnal Socioscientia 4(2): 255-260.

Kapur D, Gualu AK. 2012. Financial performance and ownership structure of Ethiopian commercial banks. Journal of Economics and International Finance 4(1): 1-8.
KurtH, GrahamF.2004.Costincomeratiobenchmarking in banking: a case study. Benchmarking: An International Journal 11(3): 303-319. https:// doi.org/10.1108/14635770410538772.

Marsuki M, Pahlevi C, Pono M. 2012. Perbandingan kinerja keuangan bank pemerintah dan bank swasta nasional. Jurnal Analisis 1(1): 67-72.

Mewengkang YR. 2013. Analisis perbandingan kinerja keuangan bank pemerintah dan bank umum swasta nasional yang tercatat di BEI. Jurnal Riset Ekonomi, Manajemen, Bisnis dan Akuntansi 1(4): 344-354.

Nasta IW. 2004. Analisis kinerja bank umum nasional devisa di Indonesia dengan metode radar [tesis]. Bogor: Institut Pertanian Bogor.

Pasaribu RBF. 2008. Pengaruh variabel fundamental terhadap harga saham perusahaan go public di BEI. Jurnal Ekonomi dan Bisnis 2(2): 101-113.

Pratiwi A. 2001. Analisis cluster strategis dengan metode radar pada kelompok bank umum di Indonesia [tesis]. Depok: Universitas Indonesia.

Purwaningrum E. 2011. Factors affecting price earning ratio of company's share in the manufacture sector. Jurnal Ekonomi dan Bisnis 10(1): 4751.

Purwoko A, Sussanto H. 2008. Perbandingan kinerja antara bank pemerintah dan bank swasta periode 2001 - 2006. Jurnal Ekonomi Bisnis 13(2): 122 128.

Sutriani A. 2014. Pengaruh profitabilitas, leverage dan likuiditas terhadap return saham dengan nilai tukar sebagai variabel moderasi pada saham LQ-45. Journal of Business and Banking 4(1): 67-80. https://doi.org/10.14414/jbb.v4i1.294.

Tanggulungan G. 2012. Komparasi kinerja bank pemerintah dan bank swasta. http://eprints. unisbank.ac.id/id/eprint/162 [ 18April 2015].

Wijayanti. 2010. Analisis kinerja keuangan dan harga saham perbankan di Bursa Efek Indonesia (BEI). Journal of Indonesian Applied Economics 4(1): 71-80. https://doi.org/10.21776/ ub.jiae.2010.004.01.1. 